Модальное значение невозможности осуществления действия, а также значение запрета, непозволительности выражается сочетанием инфинитива и модального слова ярамай: һуңларва ярамай, карарва ярамай. Примеры: Хатип менән исәппәшеп торорға ярамай (Ф.Исянгулов). Бер азым артка сигенергә ярамай!

Значение невозможности действия может передаваться аналитической формой, состоящей из глагола с аффиксом -мальl, -мәле и модальным словом түгел: үтмәле түгел, карамаль түгел. Пример: Был баланың өсттөнә карамалы түгел (Т.Кильмухаметов).

Значение возможности и невозможности также может передаваться следующими аффиксами:

1. -ырльк, -ерлек (-орлок, -өрлөк, -рльлк, -рлөк). Примеры: Типһә тимер өзөрлөк (М.Карим). Баш китерлек эштәр эшләйһегез (Х.Давлетшина).

Отрицательная форма образуется по-разному:

А) при помощи аффикса отрицания -ма, -мә: барырлыљ - бармасллькк, үтерлек - үтмәслек. Пример: Күз һалмаслык егет түгел;

Б) при помощи модального слова түгел: барырлык түгел, үтерлек түгел, укырлыл түгел. Пример: Кызғаныска каршы, медальон укырлык түгел (Газетанан);

В) при помощи вспомогательного глагола бул- в отрицательной форме: барырлык булмаван, күтәрерлек булмаван. Пример: Был бала тыуғанда ук йәшәрлек булмаған (Газетанан).

2. - -ырзай, -ерзәй (-орзай, -өрзәй). Эта форма обычно выражает более или менее уверенное предположение говорящего в возможности осуществления того или иного действия. Примеры: Бер з̧ә кулдан килерзəй эш булмағанға окшай (Т.Кильмухаметов). Теш ұтерзәй кешегә окшамаған (Т.Кильмухаметов).

3. В башкирском языке активно используются формы с аффиксами кblhblз, -кеhез, -кылай, -келәй и др., которые выражают значение невозможности. Примеры: Күз аскыһыз буранда азашып куймаһын (Н.Мусин). Йырып сыккыһыз бысрак.

Таким образом, в башкирском языке для выражения значений возможности и невозможности используются различные аналитические глагольные формы и конструкции, а также аффиксы. Данные формы передают различные оттенки модальных отношений возможности и невозможности.

$$
* * *
$$

1. Грамматика современного башкирского литературного языка / Отв. редактор А.А.Юлдашев. М.: Наука, 1981. 496 с.

2. Зайнуллин М.В. Система лексических и лексико-грамматических средств выражения модальных значений в современном башкирском языке. Уфа: БДУ, 1981. 82 с.

3. Зайнуллин М.В. Модальность как функционально-семантическая категория: На материале башкирского языка. Саратов: Изд-во Саратовского университета, 1986. 123 с.

4. Зайнуллин М.В. О сущности и границах категории модальности в башкирском языке. Уфа: БГУ, 2000. 293 с.; Уфа: БГУ, 2013. 380 с.

5. Зәйнуллин М.В. Хәзुерге башкорт телендә модаллек категорияһы. Өфө, 1975. 165 бит.

\title{
Кандыбина А.В. \\ Структурно-семантические характеристики русских и чешских паремий в рамках универсальной антиномии «богатство-бедность»
}

ФГАОУ «Волгоградский государственный университет» (Россия, Волгоград)

doi: $10.18411 / \mathrm{j}-06-2021-126$

\section{Аннотация}

В настоящей работе описаны паремии русского и чешского языков с семантическим центром «образ животного» в рамках антиномии «богатство-бедность». 
Выявлены основные структурные модели и семантические компоненты пословиц и поговорок. Определены характерные черты родственных лингвокультур, отражающие особенности менталитета разных славянских народов.

Ключевые слова: антиномия, богатство / бедность, паремия, паремиология.

\section{Abstract}

This work presents the characteristics of the Russian and Czech language paremias with the semantic center " animal image " within the antinomy "wealth-poverty". The main structural models and semantic features of proverbs are described. The characteristic features of related linguistic cultures, reflecting the peculiarities of the mentality of different Slavic peoples, were established.

Keywords: antinomy, wealth / poverty, paroemia, paremiology.

Паремиология как самостоятельная научная дисциплина в рамках лингвистики имеет относительно недолгую историю развития. По утверждению Е.А. Койранской, «в отечественной науке о языке особый интерес к паремиям наблюдается с конца XIX в. XX в.» [Койранская 2011, с. 257]. Однако нельзя сказать, что за столь короткий срок данная наука не достигла определенных результатов в области исследования паремичных единиц. Скорее наоборот, паремиология стала одной из ведущих дисциплин, исследующих идиоматику в её широком понимании. Обращаясь к данной проблеме, В. М. Мокиенко говорит о повышенном внимании исследователейфразеологов именно к пословицам и поговоркам как "представителям" паремий: «Многие из них посвятили паремиологии часть своей фразеологической жизни, а некоторые давно уже отдали предпочтение именно пословицам, не дав полного «развода» фразеологии в узком смысле слова» [Мокиенко 2010, с. 6]. Сравнительная паремиология является основным направлением изучения паремичных единиц, главная задача которого заключается в выявлении общего и индивидуального в паремиях разных языков в результате их сопоставления по определенным критериям. Особую ценность в данном отношении представляют понятия, отражающие наиболее значимые для человека аспекты жизнедеятельности, так как они обнаруживают непосредственную связь с универсальными антиномиями. Язык по своей сущности «система живая, и как средству межкультурной коммуникации языку присущи такие качества, как спонтанность и антиномичность» [Егорова 2006, с. 257].

Антиномия «богатство-бедность» репрезентирует человека с позиции обладателя материальных благ. В рамках общепринятых представлений уровнем достатка оценивается успешность и степень реализации заложенных в каждом индивиде природных и социально приобретённых возможностей. Понятия, составляющие рассматриваемую семантическую оппозицию, носят универсальный характер, что объясняет их активное закрепление в сознании носителей различных языков. Вместе с тем специфика национального мировосприятия накладывает особые семантические оттенки на языковые единицы, отражающие категории богатства и бедности. Важно отметить, что структурная организация паремичных единиц часто определяет смысловую доминанту, составляющую основу значения пословицы или поговорки. Это дает возможность рассматривать семантические и структурные особенности паремий во взаимодействии.

Среди паремий с сематическим ядром «образ животного» в русском языке особое место занимают пословицы, построенные по модели сравнения. Лексемы мышы, щука, зубр, медведь, лев выступают в качестве центрального компонента, основные грани значения которого соотносятся с понятиями богатства и бедности. Обычно характерная черта зверя, отражающая особенности его существования, повадки и своеобразность поведения, является общеизвестной для носителя языка, и поэтому дает возможность усилить абстрактное представление доказательством при помощи 
сравнительного оборота с союзами как, что: Богатый в деньгах, что мышь в крупах; Простор богатому, как щуке в воде. Следует подчеркнуть, что в данных примерах функционирует синтаксическая модель: богатый..., как [образ животного] в... Пословицы подтверждают общеизвестные факты: богатство всегда характеризуется наличием денег и предполагает вольную беззаботную жизнь. В случаях Житье, что беловежскому зубру; Богатый селен, что медведь; Богат силен, что лев реализуется иная структура, которая позволяет определить радиус влияния богатого человека не только на свою жизни, но и н жизни других людей. Физическая сила животных приравнивается к всеобъемлющей силе материального благосостояния, за счет которого можно приобрести даже то, что не оценивается в денежном эквиваленте.

Особого внимание в данной группе заслуживают паремии, имеющие композицию развертывания, так как в них не представлен образ определенного живого существа. Акцент делается на какой-либо признак, характерный для определенной совокупности животных. Например, пословица Буду богат, буду рогат; кого захочу, того избоду не просто репрезентирует рога как особенность внешнего вида домашних и диких животных, а выделяет важную функцию этой части тела: средство нападения и защиты. В целом значении паремичной единицы полностью эквивалентно семантике пословиц и поговорок, представленных выше. Однако употребление глаголов в форме 1 лица единственного числа определяет субъективное отношение человека к собственному возможному богатству. Структура развертывания заостряет внимание на центральном компоненте значения: вторая часть оправдывает появление того или иного образа в первой.

Объединение сравнительных оборотов и поясняющих их конструкций образуют структуру сравнения-развертывания: Кормна лошадь, так и добра; богат мужик, так и умен; Богатый, что скот рогатый, в тесные врата не пройдет. Такая композиция упрощает понимание пословицы, трактует значение паремии. В первом случае частотный образ накормленной лошади соотносится с богатым человеком, сравниваются качества этих семантических субъектов. Следует отметить, что в паремии используются краткие прилагательные, одно из которых представляет собой древнюю морфологическую форму кормна. Во втором случае образ животного является обобщенным и выражается словосочетанием скот рогатый.

В пословицах, построенных по принципу противопоставления, могут использоваться противительные союзы: Шуба овечья, да душа человечья, или бессоюзную связь: У рака мочь в клешне, у богача в мошне. Амбивалентность может быть выражена по разным признакам, относиться к разным субъектам. В первом случае речь идет об одном человеке, о противопоставлении его внешнего и внутреннего обликов. Во втором, с одной стороны, представлен образ рака, с другой - образ богача, что указывает на разграничение данных субъектов. При этом употреблены такие лексемы, как клешня и мошна, которые приобретают метафорическое значение, являясь символом средства выживания. Обозначение разных реалий: часть тела живого существа и мешочек для денег позволяет вывести главную семантическую особенность пословицы. Наличие денег является определяющим фактором в устранении любой проблемы, даже если человек не обладает ни умственными, ни физическими способностями.

Композиция отрицания реже, чем названные выше, выступает моделью образования пословиц и поговорок. Обычно она строится при помощи повторяющегося сочинительного союза ни..., ни: Ни конь без узды, ни богатство без ума. Такая структура позволяет акцентировать внимание на необходимых качествах, позволяющим правильно распорядиться материальными средствами. Параллелизм с предметом снаряжения коня служит приемом подтверждения информации, расположенной во второй части пословицы. 
В рассматриваемой группе паремий встречаются образы общеизвестных русскому человеку животных; употребляются обобщенные наименования, выраженные моделью $\mathrm{Adj}+\mathrm{N}$ типа рогатый скот, а также обнаруживаются случаи замены обозначения того или иного вида животного каким-либо словосочетанием, хранящим в своем значение упоминание об особенности этого животного: овечья щуба. В структуре преобладающее место занимают паремии, имеющие композицию сравнения.

Среди чешских пословиц и поговорок распространены схожие структурные комплексы. Сравнительные композиции обычно используют союз jak: Chlap bohatý, jak býk rohatý (Человек богатый, как бык рогатый). Данная пословица обнаруживает эквивалентное значение с русскими паремиями, где животное, имеющее рога, сравнивается с богатым человеком. Следует отметить, что в чешском языке используется конкретное видовое название животного: býk rohatý, а в русском обобщенное, родовое: рогатый скот.

Паремии-развертывания имеют двухчастную композицию: Když se žebrák na koně dostane, ani čert ho nedohoní (Когда нищий садиться на лошадь, черт его достать не может); Kdo má koné, snadno $k$ пе̌ти sedlo najde (Кто имеет коня, тот легко найдет ему седло). В данных примерах употребляется образ такого важного сельскохозяйственного животного, как конь, для приобретения которого требовался стартовый капитал. В связи с этим значение пословицы строится на основании перенесения общеизвестных фактов и реалий на характеристику богатого человека. Как прием речевого воздействия данная паремия может применяться в качестве тонкого иронического штриха, подчеркивающего скупость.

Помимо двухчастных структур чешские пословицы и поговорки используют одночастные композиции, что указывает на лаконичный характер мышления носителей чешского языка. Обычно использование двух образов параллельно дает возможность наиболее точно охарактеризовать степень того или иного качества. Например, в паремии Chudému vždycky spíše v saku žába než rak (Бедный скорее поймает жабу, чем рака) внимание акцентируется на невезение бедных людей. Образ жабы ассоциируется с чем-то неприятным, постоянно затрудняющим ход жизненных событий. В то время как образ речного рака эксплицирует удачу, размеренность и лёгкость в решении возникающих проблем. Кроме того, повторение одинаковых лексем, относящихся к разным словам, также способно указать на семантический центр паремии. В случае Veliký pták velikého hnizda liotřebuje (Большая птица требует большого гнезда) дважды употреблено прилагательное veliký, которое в данном контексте позволяет говорить о потребностях людей, имеющих высокий достаток. Выявляется закономерность: чем богаче человек, тем больше его требования. Важно отметить, что в поговорке употреблен обобщенный образ птицы, выраженный лексемой pták, что говорит об абстрактности мышления чешского народа.

Анализ структурно-семантических особенностей русских и чешских паремий дает возможность сделать следующие выводы: в русском языке двухчастные композиции преобладают над одночастными структурами; в чешском наблюдается обратная зависимость. В первую очередь, данный факт объясняется конкретным мышлением русского человека, способностью к детализации внеязыковых ситуаций интралингвистическими средствами. Образы животных обладают национальной семантической нагрузкой, что выражается в контексте паремичных выражений. В обеих лингвокультурах обнаруживаются случаи завуалированной репрезентации тех или иных образов, выражающиеся в трактовке характерных черт живого существа, соотносящихся с качествами человека. Значение «деньги - главное оружие человека; средство достижения любой цели» свойственно как русскому, так и чешскому языкам, что акцентирует внимание на универсальности данной реалии. В русских пословицах представлена семантика, выражающая необходимость осторожного, обдуманного 
отношения к материальным ценностям; в чешских особо отмечается высокомерность и скупость богатых людей.

1. Егорова, С. Б. Павел Флоренский об антиномиях языка / С. Б. Егорова// Вестник саратовского государственного технического университета. - 2006. - № 1. - С. 256-262.

2. Койранская, Е. А. Разностороннее изучение паремий в русской и зарубежной лингвистике / Е.А. Койранская. - Вестник Орловского государственного университета. - 2011. - № 1. - С. 257-259.

3. Мокиенко, В. М. Современная паремиология (лингвистические аспекты) / В. М. Мокиенко // Мир русского слова. - 2010. - № 3. - С. 6-17.

\section{Кувшинова Г.П.}

Деловой разговор по телефону: этические нормы речевого общения на английском языке в типичной ситуации

Карачаево-Черкесский государственньий университет имени У.Д. Алиева (Россия, Карачаевск)

doi: $10.18411 / \mathrm{j}-06-2021-127$

\section{Аннотация}

Статья нацелена на выделение специфического языкового корпуса в свете конкретного вида коммуникации в деловом английском языке (этика телефонного разговора). Акцент ставится на этические нормы речевого общения в профессиональном контексте. Работа носит прикладной характер, т.е. помогает студентам актуализировать знание норм, стереотипов и правил речевого этикета применительно к конкретным условиям реального речевого общения. Исследуются способы и умения эффективного общения в конкретной деловой ситуации с точки зрения этики. Исследование показало, что современные тенденции в теории обучения языку направлены на изучение реального языкового функционирования в различных сферах и ситуациях общения.

Ключевые слова: этика, формула речевого этикета, оборот речи, приветствие, прощание, благодарность, приглашение, извинение, ситуация, деловой английский язык, аспект речи, коммуникация.

\section{Abstract}

The article is aimed at the singling out of specific linguistic frame in the light of concrete aspect of communication in Business English (the ethics of telephone conversation). The ethical standards of speech behavior in professional context are stressed. The work has applied character, that is to say it helps the students to actualize the knowledge of standards, stereotypes and rules of speech in reference to concrete etiquette conditions of real professional communication. The methods and abilities of effective intercourse in concrete business situation are investigated from the ethics point of view. The investigation proved that modern tendencies in the theory of language teaching are trended to the study of real linguistic functioning in different spheres and situations of communication.

Keywords: ethics, formula of speech etiquette, turn of speech, greetings, saying good-bye, thanks, invitation, apology, situation, Business English, aspect of speech, communication.

Известно, что деловой иностранный язык продолжает вызывать пристальный интерес как среди тех, кто хочет им овладеть так и среди тех, кто стремится найти эффективные способы обучения. И все же, не смотря на огромный интерес деловой иностранный язык остается областью мало изученной языковедами. Действительно, деловой иностранный язык можно рассматривать в общем контексте иностранного 